\title{
Impact of Pandemic in the Frequency of Scabies: Possible Scabies Outbreak Scenario Aftermath COVID-19
}

\author{
Pandeminin Skabiyez Sıklığ Üzerindeki Etkisi: COVID-19 Sonrasinda \\ Olasz Skabiyez Salginz Senaryosu
}

\section{(1) Çağrı Turan, (1) Nurcan Metin}

University of Health Sciences Turkey, Erzurum Regional Training and Research Hospital, Clinic of Dermatology and Venereology, Erzurum, Turkey

Cite this article as: Turan Ç, Metin N. Impact of Pandemic in the Frequency of Scabies: Possible Scabies Outbreak Scenario Aftermath COVID-19. Turkiye Parazitol Derg 2021;45(3):190-194.

\begin{abstract}
Objective: This study aimed to evaluate the post-pandemic changes in the frequency of scabies and determined the clues that may indicate a possible outbreak of scabies in the future.

Methods: All patients diagnosed with scabies in the University of Health Sciences Turkey, Erzurum Regional Training and Research Hospital and Palandöken State Hospital between January 2019 and September 2020 were evaluated.

Results: The frequency of scabies of $1.87 \%$ was remarkable in the first quarter of 2020, which corresponds to the pre-pandemic, and $>50 \%(n=442)$ of all patients with scabies in $2019(n=769)$ were encountered only in the first 3 months. The frequency of scabies seen in the first 3 quarters of 2020 was significantly higher than in 2019 ( $p<0.001)$. Significant decreases were found in the 0-14 years age groups (infant, preschool and school period) compared to 2019 ( $p<0.001, p<0.001$ and $p=0.015$, respectively). No significant increase or decrease was determined in the frequency of scabies in 2020 ( $p=0.205)$. In addition, an increase in the number and rates of scabies patients are observed after the first month of normalisation period followed by the increase in the number of Coronavirus disease-2019 (COVID-19) daily cases.

Conclusion: Applications for scabies to polyclinics after the pandemic were determined to be too low compared to previous periods, especially in school-age children, and showed an increasing trend over time. Patients with scabies that reach treatment late or not due to the pandemic may cause outbreak aftermath COVID-19.
\end{abstract}

Keywords: Epidemiology, scabies, COVID-19, pandemic, outbreak

\section{ÖZ}

Amaç: Skabiyez sıklığındaki değişimle ilgili olarak pandemi salgını sonrası tablonun değerlendirilmesi ve gelecekte olası bir skabiyez salgınına işaret edebilecek ipuçlarınının araştırılması amaçlanmaktadır.

Yöntemler: Çalışmada, Ocak 2019-Eylül 2020 tarihleri arasında Sağlık Bilimleri Üniversitesi, Erzurum Bölge Eğitim ve Araştırma Hastanesi ile Palandöken Devlet Hastanesi'nde skabiyez tanısı alan tüm hastalar değerlendirilmiştir.

Bulgular: Pandemi öncesi, 2020 yılının ilk çeyreğinde skabiyez görülme sıklığının \%1,87 olması ve 2019 yılındaki skabiyez hasta sayısının yarısından fazlasının (n=442) (n=769) 2020 yllının sadece ilk 3 ayı içerisinde görülmesi dikkat çekicidir. 2020 yılının ilk 3 çeyreğindeki skabiyez görülme sıklığı, 2019 yıllına göre göre anlamlı derecede yüksektir ( $<<0,001)$. S1fır-on dört yaş grubunda (bebek, okul öncesi ve okul dönemi) 2019 yılına göre anlamlı düşüşler saptanmıştır (sırasıyla; $p<0,001, p<0,001, p=0,015)$. 2020 yılı boyunca skabiyez sıklığında önemli bir artış veya azalma olmadığı tespit edilmiştir ( $\mathrm{p}=0,205)$. Normalleşme döneminin ilk ayından sonra skabiyez hastalarının sayı ve oranında artış olduğu, ardından günlük Koronavirüs hastalığı-2019 (COVID-19) olgu sayısında da artış olduğu kaydedilmiştir.

Sonuç: Pandemi sonrasında polikliniklere yapılan uyuz başvurularının özellikle okul çağındaki çocuklarda önceki dönemlere göre çok düşük olduğu ve zamanla artış eğilimi gösterdiği belirlenmiştir. Pandemi nedeniyle tedaviye geç ulaşan veya ulaşmayan skabiyez hastalarının COVID-19 pandemisi sonrasında bir skabiyez salgınına neden olabileceği değerlendirilmektedir.

Anahtar Kelimeler: Epidemiyoloji, skabiyez, COVID-19, pandemi, salgın

Address for Correspondence/Yazar Adresi: Nurcan Metin, University of Health Sciences Turkey, Erzurum Regional Training and Research Hospital, Clinic of Dermatology and Venereology, Erzurum, Turkey

Phone/Tel: +90 5075806255 E-mail/E-Posta: drnurcanmetin@hotmail.com ORCID ID: orcid.org/0000-0002-1251-6333 


\section{INTRODUCTION}

The emergence of the severe acute respiratory syndromecoronavirus-2 (SARS-CoV-2) and its rapid spread to the whole world has opened the door to new standards and regulations in many areas of life, especially health (1). After the first confirmed case on March 11, 2020, the crisis period started in our country, and the normalization process started with the control of the number of cases on June 1, 2020. However, a second crisis period has started as of August 15 with the number of Coronavirus disease-2019 (COVID-19) daily cases that started to increase at the beginning of August. During these crisis periods, we, as dermatologists, had to take an active mission and primary responsibility in all fields from outpatient clinics to intensive care units related to COVID-19. In several studies, it has been pointed out that there are significant changes in the number and profile of outpatient clinic applications due to the measures, regulations, and the COVID-19 risk perception of the patients $(2,3)$. It was reported that the number of patients who applied to dermatology outpatient clinics during the crisis period decreased by 5 times (2).

Scabies is not a notifiable disease in Turkey, caused by Sarcoptes scabiei var. hominis. The infectivity of scabies does not disappear and result in severe infestations if left untreated (4). We have reported that the incidence of scabies, which started to increase in our country since the second half of 2019, became more pronounced in the last quarter of the year (5). In a recent study, we reported that approximately $2 \%$ of the patients who applied to the dermatology outpatient clinics in the pre-pandemic period in 2020 had scabies, which rephrases a worse picture than the last year. Though the number of applications had decreased in the post-pandemic, interestingly the rate of scabies represented no change significantly $(2,5)$. This situation leads to an essential suspicion that many patients do not reach the suitable treatment or delay their treatment in a disease such as scabies that impairs quality of life. Because scabies, which we have already encountered very often in our country, may lead to an epidemic owing to patients who do not take effective treatment. Measures such as post-pandemic social distance rules and some other similar restrictions may delay experiencing this anticipated increase of scabies frequency. However, it is reasonable to expect more scabies patients upon increasing human interaction after vaccination and normalization. In the study, we aim to evaluate the post-pandemic picture on the change in the frequency of scabies and if our hypothesis is accurate, to look for clues that may indicate a possible outbreak of scabies in the future.

\section{METHODS}

All patients who applied to the Department of Dermatology and Venereology in the Regional Training and Research Hospital and Palandöken State Hospital affiliated with the training hospital, between 01 January 2019 and 15 September 2020, were enrolled in the study, regardless of their diagnosis. Data such as age, gender, application dates, ICD-10 (International Classification of Diseases- $10^{\text {th }}$ Revision) codes were received from the hospital database by anonymizing. All patients have been diagnosed with clinical or suspected scabies based on the clinical evaluation by a dermatology specialist. All repeated applications within ten days after the previous application were considered trivial and were excluded from the records before statistical analysis.
No patient consent was needed, providing names and citizenship numbers were anonymized by the IT team and with the approval of the ethics committee. This single-center cross-sectional study was approved by the Ethics Committee of Regional Training and Research Hospital, Erzurum, Turkey (decision no: 2020/120-190), and the Ministry of Health Scientific Research Platform (application form number: 2020-10-01T13_14_47). It was performed according to the tenets of the latest version of the "Helsinki Declaration" and "Guidelines for Good Clinical Practice".

\section{Statistical Analysis}

All statistical procedures were conducted using IBM SPSS Statistics 21.0 and MS-Excel 2010. Firstly, we checked the normality distribution of scale variables by KolmogorovSmirnov. Pearson chi-square and Mann-Whitney U tests were used for categorical and scale variables, respectively. Results were presented as the median (interquartile range) or the number of patients (percentage). In chi-square tests with a degree of freedom greater than 1, pairwise comparisons (post-hoc) were performed using the z-test with correction for alpha inflation (Bonferonni style). Two-sided p-values of $<0.05$ were considered statistically significant.

The daily number of newly diagnosed COVID-19 cases and the number of scabies patients for 2-week periods applied to our dermatology outpatient clinics were presented with the same "scatter with straight lines" graphic. The change in the proportion of patients with scabies throughout the year is also presented as a graph. The graph of "novel coronavirus daily cases in Turkey" was adapted from the Worldometer, a reference website that provides real-time world statistics (6). Graphics were presented as monthly changes after dividing a year into 24 parts.

\section{RESULTS}

After the control patients were excluded, a total of 122,627 patients, 1.551 of which were diagnosed with scabies and were evaluated in our outpatient clinics since the beginning of 2019. The frequencies of scabies according to the quarters in 2019 and 2020 were presented in Table 1. The increase in the frequency of scabies, which emerged in the second half of 2019, became apparent in the last quarter and there was no decrease in their frequency throughout 2020 (Table 1, Figure 1). It was remarkable that the frequency of scabies was $1.87 \%$ in the first quarter of 2020, which corresponds to the pre-pandemic, and that more than half $(n=442)$ of all patients with scabies in $2019(n=769)$ were encountered only in the first 3 months. The frequency of scabies seen in the first 3 quarters of 2020 was significantly higher than in 2019 ( $\mathrm{p}<0.001)$. When the change in the age distribution of the scabies patients in Table 2 was examined, significant decreases were found in the 0-14 age groups (infant, preschool, and school period) compared to 2019 ( $\mathrm{p}<0.001, \mathrm{p}<0.001$, and $\mathrm{p}=0.015$, respectively) (Table 2 ).

Quarters 2 and 3 of 2020 correspond to the pandemic period, and significant fluctuations were observed in the number and rates of patients with scabies during these periods (Figure 1). It was determined that there was no significant increase or decrease in the frequency of scabies during 2020 ( $p=0.205$ ). However, as seen in Figure 1, it was exceptional that there was an unusual 


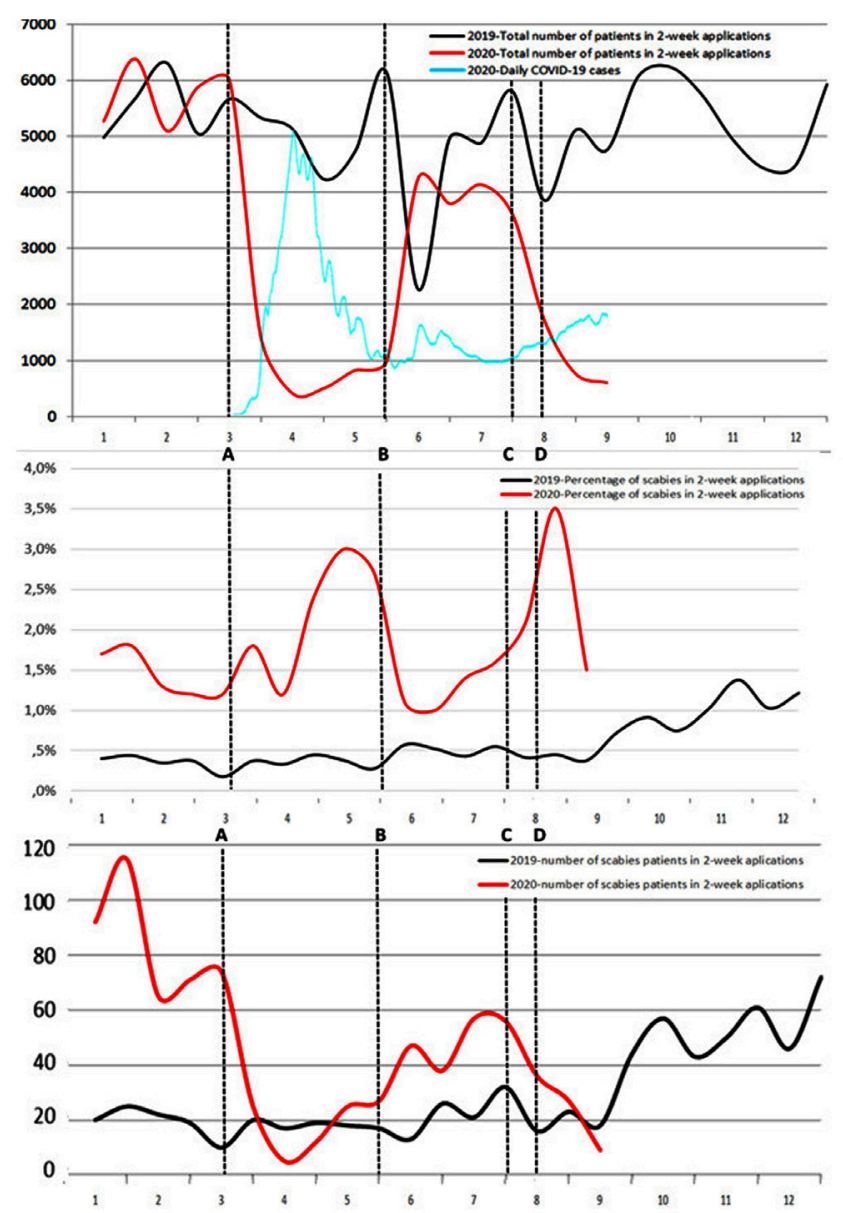

Figure 1. Change in the number of applications to dermatology and the rate of scabies and daily COVID-19 patients

A-B: $1^{\text {st }}$ crisis period, B-C: Normalization period, after $C: 2^{\text {nd }}$ crisis period

All graphics were presented as monthly changes after dividing a year into 24 parts, with reference to the 2 -week patient application numbers. In the top graphic, the number of patients applied to the dermatology outpatient clinic in 2019 and 2020, and the number of daily COVID-19 cases were presented from our hospital and across the country, respectively. In the last 2 graphics below, respectively, the proportion and number of scabies among all patients applied to our hospital in 2019 and 2020 were shown.

Note: While preparing this graphic, repeated applications of follow-up and control patients were not excluded.

A. March 11: The first COVID-19 case was confirmed in Turkey and the World Health Organization has declared a pandemic. The government imposed many restrictions, including curfews, over time.

B. June 1: Restrictions on inter-city travel, public places (gardens, association centers, museums, etc.), tourism areas, schools, kindergartens, and similar places were partially removed. The flexible working practice was terminated for all public employees, including hospital personnel.

C. At the beginning of August: it was observed that the number of cases in Turkey increased and the number of dermatology department applications to our hospital started to decrease.

D. August 15: Similar to our colleagues in other departments of our hospital, 7 ( $\sim 80 \%)$ of dermatologists were shifted to COVID-19 services

COVID-19: Coronavirus disease-2019

\begin{tabular}{|c|c|c|c|c|c|c|c|}
\hline \multirow[b]{4}{*}{ 管 } & \multirow{2}{*}{ 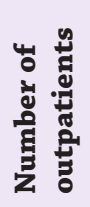 } & \multirow[b]{2}{*}{ సี } & \multicolumn{4}{|c|}{ Quartiles of a year } & \multirow[b]{2}{*}{ a } \\
\hline & & & $\ddot{\sigma}$ & ช & o & $\ddot{\sigma}$ & \\
\hline & 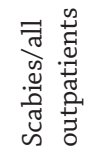 & 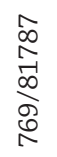 & 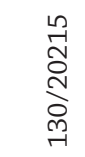 & 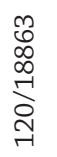 & 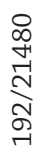 & $\begin{array}{l}\text { N } \\
\text { N } \\
\text { N } \\
\text { }\end{array}$ & \\
\hline & 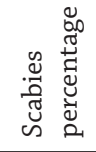 & $\begin{array}{l}\stackrel{\circ}{+} \\
\text { oे } \\
\circ\end{array}$ & $\begin{array}{l}\text { O̊ } \\
\text { லै } \\
0\end{array}$ & $\begin{array}{l}60 \\
\text { Jै } \\
0 \\
0\end{array}$ & $\begin{array}{l}\stackrel{\circ}{\circ} \\
\infty \\
0\end{array}$ & 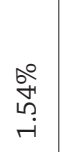 & $\begin{array}{l}\stackrel{*}{*} \\
\stackrel{*}{*} \\
\stackrel{\circ}{\circ} \\
\dot{0} \\
\dot{v}\end{array}$ \\
\hline \multirow{3}{*}{ స్ ิે } & 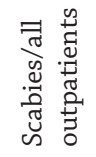 & 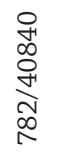 & 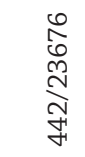 & 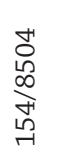 & $\begin{array}{l}t \\
0 \\
b \\
\infty \\
\infty \\
0 \\
\infty \\
-1\end{array}$ & & \\
\hline & 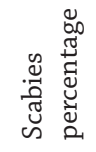 & $\begin{array}{l}\stackrel{\circ}{-} \\
\text { बై } \\
\text { - }\end{array}$ & $\begin{array}{l}\stackrel{\circ}{\circ} \\
\infty \\
+ \\
+\end{array}$ & $\begin{array}{l}\stackrel{0}{0} \\
\infty \\
-1 \\
-1\end{array}$ & $\begin{array}{l}\frac{0}{\circ} \\
\text { in } \\
\text { 건 }\end{array}$ & & $\begin{array}{l}\stackrel{2}{ } \\
\text { ก̦ } \\
0\end{array}$ \\
\hline & 2 & $\begin{array}{l}\text { ¿o } \\
\dot{0} \\
\dot{0}\end{array}$ & $\begin{array}{l}\text { is } \\
\dot{0} \\
\dot{0}\end{array}$ & $\begin{array}{l}\text { ó } \\
\text { o } \\
\dot{0}\end{array}$ & $\begin{array}{l}\text { ¿े } \\
\text { ọ } \\
\dot{0}\end{array}$ & I & \\
\hline \multicolumn{8}{|c|}{$\begin{array}{l}\text { Q1: January-March, Q2:April-June, Q3: July-September, Q4: October- } \\
\text { December, } † \text { The data are for the period between June } 1 \text { and September } \\
15 . \text { Note that data are missing for the period of } 15 \text { days, which must be } \\
\text { obtained by September } 30 \text { to complete the Q3. Pearson chi-square test was } \\
\text { used. Pairwise comparisons (post-hoc) were performed using the z-test and } \\
\text { Bonferroni correction was applied. Significant values were shown in bold. } \\
\text { ": Adjusted p-value }<0.05 \text { for the difference between Q3 and Q1, 2, 4, ": } \\
\text { adjusted p-value }<0.05 \text { for the difference between Q4 and Q1-3 }\end{array}$} \\
\hline
\end{tabular}

decrease in the number of scabies patients together with all of the dermatologic patients in the early stages of the $1^{\text {st }}$ and $2^{\text {nd }}$ crisis periods and on the contrary an unusual increase in the rate of scabies. It was noticed that there was a gradual increase in the number of patients with scabies from the middle of the $1^{\text {st }}$ crisis period to the end of the normalization period, but this was not always reflected in parallel with the rate of scabies. For this reason, it was thought that evaluating whether the rate of scabies showed an increasing tendency during the periods when the total number of dermatological patients stabilized, provided that each period was evaluated with its own internal dynamics, would allow us to make a more accurate inference. A closer look at Figure 1 showed that with the onset of the normalization process on June 1 , a quite high and stable number of total patients was reached, albeit still lower than before the pandemic. It was noted that there was an increase in the number and rates of scabies patients after the first month of the normalization period. As seen in Figure 1 , the upward trend in the frequency of scabies that emerged at the beginning of July, followed by the increase in the number of COVID-19 daily cases was interpreted as a remarkable detail. With the increase in the number of new COVID-19 cases in the country, it was observed that there was a sudden decrease in the number of patients applied to the outpatient clinic. 
Table 2. Change in age, gender and age distribution of scabies patients in the last 2 years

\begin{tabular}{|l|l|l|l|}
\hline & $\begin{array}{l}\mathbf{2 0 1 9} \\
(\mathbf{n = 7 6 9 )}\end{array}$ & $\begin{array}{l}\mathbf{2 0 2 0 \dagger} \\
(\mathbf{n = 7 8 2})\end{array}$ & $\mathbf{p}$ \\
\hline $\begin{array}{l}\text { Age (median } \\
\text { (interquartile range) }\end{array}$ & $21(23)$ & $25(25)$ & $<\mathbf{0 . 0 0 1}$ \\
\hline Sex (male/female) & $429 / 340$ & $432 / 350$ & 0.432 \\
\hline
\end{tabular}

\section{Change in the age distribution of scabies patients}

\begin{tabular}{|l|l|l|l|}
\hline Infants (0-1) & $51(6.6 \%)$ & $22(2.8 \%)$ & $<\mathbf{0 . 0 0 1}$ \\
\hline Preschool children (2-6) & $93(12.1 \%)$ & $42(5.4 \%)$ & $<\mathbf{0 . 0 0 1}$ \\
\hline School children (7-14) & $118(15.3 \%)$ & $86(11.0 \%)$ & 0.015 \\
\hline Young adults (15-44) & $375(48.8 \%)$ & $465(59.4 \%)$ & $<\mathbf{0 . 0 0 1}$ \\
\hline $\begin{array}{l}\text { Middle-aged persons } \\
\text { (45-65) }\end{array}$ & $91(11.8 \%)$ & $128(16.4 \%)$ & 0.019 \\
\hline Aged persons (65+) & $41(5.3 \%)$ & $39(5.0 \%)$ & 0.784 \\
\hline
\end{tabular}

Data were expressed as median (interquartile range) or the number of patients (percentage). Mann-Whitney U and Pearson chi-square tests were used. Significant values were shown in bold. †Data is from January 1 to August 15 Note that 3.5 months of data is missing by 31 December.

Note: Since the repeated applications of follow-up and control patients are excluded while preparing this table, percentages of scabies may differ slightly from the graphs

\section{DISCUSSION}

Scabies is an important global health problem due to the susceptibility of all age, race, gender, and socioeconomic groups to the disease, and severe itching that impairs the quality of life (7). Contamination results from direct skin contact. However, mites can survive on the inanimate objects for 24-36 hours under ordinary room conditions, and it is accepted that mites during this period can be transmitted indirectly from clothes, beds, etc. (8).

In studies reported from our country in recent years, it has been reported that the incidence of scabies has got an increasing trend $(9,10)$. Besides, we found that the increase in the frequency of scabies encountered in outpatient clinics in the $4^{\text {th }}$ quarter of the last year gained momentum and increased from $0.42 \%$ to $1.54 \%$ from 2017 to 2019 (5). Sunderkötter et al. (11) similarly reported that the frequency of scabies has increased surprisingly in Germany in recent years and they are concerned about possible permethrin resistance. In the present study, both the number and rate of patients with scabies in the first quarter of 2020 were 2 times more than in the same period of the last year. It was understood that the pre and post-pandemic periods in 2020 were statistically similar, but with a higher frequency of scabies compared to 2019, indicating that the frequency of scabies, which increased in 2019, have not tended to decrease in 2020.

We have no data on the number or rate of scabies patients applying to primary health care centers or family medicine, though it is a fact that during the pandemic, applications to all healthcare departments have decreased. In the $2^{\text {nd }}$ and $3^{\text {rd }}$ quarters corresponding to the post-pandemic period, a total of approximately 40,000 and 17,000 patients were examined in 2019 and 2020, respectively (Table 1). This extreme difference in the number of patients applied to the hospital due to the effect of the pandemic caused unusual fluctuations in the number and rate of patients with scabies shown in Figure 1. The extraordinary decreases in the number of patients during the $1^{\text {st }}$ and $2^{\text {nd }}$ crisis periods, when the number of COVID-19 daily cases increased fast, have caused the reverse effect on the rates of scabies patients. Following the unusual decrease in the number of cases with the announcement of the pandemic, the number of scabies cases gradually increased for about 3.5 months. This suggests that many scabies patients did not apply to the outpatient clinics due to the shock created by the pandemic. In a publication from Spain (12), it was reported that the frequency of scabies in the same period of the last five years (March-May) increased significantly in 2020. Policies such as social distance and "stay at home" and restricted social activities to prevent the spread of COVID-19, most probably were responsible for reduced transmission of scabies. However, it was claimed that minor outbreaks have arisen within each family group during home confinement, therefore, it is essential for patients with scabies to reach proper treatment (12).

This study was compatible with the finding from Spain (12). However, we think that interpreting the effect of the pandemic on the frequency of scabies only by comparing it to the previous years may be incomplete and/or inaccurate. Indeed, we found that there was no statistically significant difference in scabies rates between the three quarters of 2020. In such extraordinary situations, the change in the frequency of a disease in hospitalbased studies does not always indicate the incidence. Various reasons such as the effect of the relevant disease on the quality of life, the desire not to interrupt treatment, and the perception of risk can also change the diagnostic distribution in the outpatients (2). Since the sum of changes in the distribution of other diseases will reflect on the frequency of scabies, it could be misleading to explain the comparison results of crisis periods and normal periods only with incidence. So, it might be also misleading to reveal the changes in the frequency of scabies during the pandemic period with hospital-based research. Even so, reasons such as the lack of any evidence and expectation that the frequency of scabies decreased during the pandemic, increased transmission within the family, and fewer presentations than expected shall suggest that we may encounter a sudden increase in the frequency of scabies, especially after overcoming the pandemic. We think that the two-month normalization process we have experienced is a small rehearsal of our claim. As seen in Figure 1, although the number of patients applying to outpatient clinics after the first month of the normalization process was stable, there was a notable increase in the frequency of scabies. It is noteworthy that in such a period when social distance rules are more relaxed, the number of COVID-19 daily cases began to re-increase shortly after the increase in the frequency of scabies. Besides, the significant decrease in the frequency of patients in the 0-14 age group compared to the previous year suggested that the treatment of pediatric patients was delayed. We are concerned that scabies, already quite common, could cause an outbreak after the re-opening of schools closed due to the pandemic. In the literature, there are reports of scabies outbreaks in preschool and school-age childhood $(13,14)$.

\section{Study Limitations}

The most important limitations of this study are its retrospective structure and the absence of data on applications to primary health care centers. The results of our study are not generalizable although they are guiding. 


\section{CONCLUSION}

It was determined that the applications for scabies to polyclinics after the pandemic were too low compared to previous periods, especially in school-age children, and showed an increasing trend over time. Cases with scabies that reach treatment late or not due to the pandemic may cause an outbreak, especially with the opening of schools aftermath the COVID-19. Family physicians and dermatologists should be awake in this regard. However, studies with higher levels of evidence are needed on this subject.

\section{* Ethics}

Ethics Committee Approval: This single-center cross-sectional study was approved by the Ethics Committee of Regional Training and Research Hospital, Erzurum, Turkey (decision no: 2020/120-190), and the Ministry of Health Scientific Research Platform (application form number: 2020-10-01T13_14_47). It was performed according to the tenets of the latest version of the "Helsinki Declaration" and "Guidelines for Good Clinical Practice".

Informed Consent: No patient consent was needed, providing names and citizenship numbers were anonymized by the IT team and with the approval of the ethics committee.

Peer-review: Internally peer-reviewed.

\section{* Authorship Contributions}

Surgical and Medical Practices: Ç.T., N.M., Concept: Ç.T., Design: Ç.T., Data Collection or Processing: Ç.T., N.M., Analysis or Interpretation: Ç.T., Literature Search: Ç.T., N.M., Writing: Ç.T., N.M.

Conflict of Interest: No conflict of interest was declared by the authors.

Financial Disclosure: The authors declared that this study received no financial support.

\section{REFERENCES}

1. Rudnicka L, Gupta M, Kassir M, Jafferany M, Lotti T, Sadoughifar R, et al. Priorities for global health community in COVID-19 pandemic. Dermatol Ther 2020; 33: e13361.
2. Turan Ç, Metin N, Utlu Z, Öner Ü, Kotan ÖS. Change of the diagnostic distribution in applicants to dermatology after COVID-19 pandemic: What it whispers to us? Dermatol Ther 2020; 33: e13804.

3. Gao C, Liu B, Xie Y, Wu Z. Change of dermatological practice after the COVID-19 outbreak resolves. J Dermatolog Treat 2020: 1-3.

4. Nair PA, Vora RV, Jivani NB, Gandhi SS. A Study of Clinical Profile and Quality of Life in Patients with Scabies at a Rural Tertiary Care Centre. J Clin Diagn Res 2016; 10: WC01-WC5.

5. Turan Ç, Metin N, Utlu Z. Epidemiological Evaluation of Scabies Cases Encountered in the Last Three Years as a Tertiary Health Center. Turkiye Parazitol Derg 2020; 44: 77-82.

6. COVID-19 Coronavirus Pandemic. Worlometers website. Updated Oct 25, 2020. (cited 2020 Oct 30). Available from: URL: https://www. worldometers.info/coronavirus/

7. Tarbox M, Walker K, Tan M. Scabies. JAMA 2018; 320: 612.

8. Falay T, Gürel MS. Uyuz. Turkiye Klinikleri J Dermatol-Special Topics 2017; 10: 143-53.

9. Çetinkaya Ü, Sahin S, Ulutabanca RÖ. Kayseri İlinde Scabies ve Pediculosis Epidemiyolojisi [The Epidemiology of Scabies and Pediculosis in Kayseri]. Turkiye Parazitol Derg 2018; 42: 134-7.

10. Aktaş H, Cebecik A. Changes in incidence and age distribution of scabies: A retrospective cohort study in a tertiary hospital. Arch Clin Exp Med 2019; 4: 21-4

11. Sunderkötter C, Aebischer A, Neufeld M, Löser C, Kreuter A, Bialek R, et al. Increase of scabies in Germany and development of resistant mites? Evidence and consequences. J Dtsch Dermatol Ges 2019; 17: 15-23.

12. Martínez-Pallás I, Aldea-Manrique B, Ramírez-Lluch M, Manuel VinuesaHernando J, Ara-Martín M. Scabies outbreak during home confinement due to the SARS-CoV-2 pandemic. J Eur Acad Dermatol Venereol 2020; 34: e781-e3.

13. Weigl JAI. Fallhäufungen von Skabies an Schulen und Einsatz von Ivermectin [Outbreaks of Scabies in Schools and Use of Ivermectin]. Gesundheitswesen 2018; 80: 360-4.

14. Kaburi BB, Ameme DK, Adu-Asumah G, Dadzie D, Tender EK, Addeh SV, et al. Outbreak of scabies among preschool children, Accra, Ghana, 2017. BMC Public Health 2019; 19: 746. 